\title{
Phenotypic Conversion of SV40-Immortalized Human Diploid Fibroblasts to Senescing Cells by Introduction of an Antisense Gene for SV40-T Antigen
}

\author{
Yoshiharu Tanaka ${ }^{*}$, Xiaoren Tang ${ }^{1}$, De-Xing Hou ${ }^{1}$, Hui Gao ${ }^{1}$, Issay Kitabayashi ${ }^{1}$, Gabriel \\ Gachelin $^{2}$ and Kazushige Yokoyama ${ }^{1,2 * *}$ \\ ${ }^{1}$ Gene Bank and ${ }^{2}$ Frontier Research Program, Tsukuba Life Science Center, RIKEN (The Institute of Physical \\ and Chemical Research), 3-1-1 Koyadai, Tsukuba, Ibaraki 305, Japan
}

Key words: SV40-T/antisense RNA/human diploid fibroblast/phenotypic conversion

\begin{abstract}
$A B S T R A C T$. Normal human lung fibroblast diploid cells, WI-38, become senescent after a definite number of divisions. VA-13 is a line of immortalized cells established by transformation of WI-38 cells by SV40 virus. To determine whether SV40 large $T$ (SV40-T) antigen is essential for this immortalization of WI-38 cells we introduced an antisense gene for $T$ antigen into VA-13. Two morphologically different types of antisense transformant (VA-AS5-8 and VA-AS37-8) were obtained. In both antisense transformants the expression of $T$ antigen was reduced by more than $70 \%$ as compared to that in the parent cells. The morphology of the antisense transformants indicated a partial conversion to the senescent phenotype of WI-38. The relative number of cells in the $S$ phase of the antisense transformants was decreased as compared to that in cultures of VA-13 and about $50 \%$ of cells were at $\mathbf{G}_{1 / 0}$. The doubling time of the transformants was prolonged to close to the doubling time of WI-38. The level of expression of retinoblastoma protein (pRB) complexed with SV40-T antigen of the antisense transformants was significantly decreased although the level of total pRB was much higher than that in VA-13. The pRB was present exclusively in the underphosphorylated form. Thus, the decreased level of formation of the complex between SV40-T and pRB or the underphosphorylation of pRB may explain the suppression of growth of antisense transformants. Together, these results show that an antisense gene for SV40-T antigen can efficiently block the cell proliferation and the cell immortalization of VA-13 cells.
\end{abstract}

Normal human diploid fibroblasts have an inherent capacity for limited proliferation potential. The continued cultivation of these cells results in senescence and crisis after a definite number of passages in vitro. The differences between aged cells and the cells in primary culture are as follows: a decreased capacity for cell proliferation; arrest at the $\mathrm{G}_{1 / 0}$ phase; and morphological changes $(21,23,34)$. The VA-13 cell line (subline 2RA, ref. 18 ) is the simian virus-mediated (SV40-mediated) transformant of WI-38, which is a line of normal human diploid fibroblast cells. This transformed cell line is considered to have bypassed the crisis, probably by exploitation of the large T (SV40-T) antigen of SV40 for its many functions that facilitate the immortalization and transformation of normal cells. If the immortalization of WI-38 is due to the functions of the SV40-T antigen, it might be expected that the characteristics of the

\footnotetext{
* Present address: Department of Life Sciences, College of Integrated Arts and Sciences, University of Osaka Prefecture, Sakai, Osaka 591, Japan.

** To whom correspondence and requests for reprints should be addressed.
}

VA-13 cells would revert to those of senescent cells if one could limit or block the function of the SV40-T antigen. We used antisense RNA technology $(20,44,48)$ to clarify the roles of SV40-T antigen in the process involved in bypassing senescence, with emphasis on the involvement of the $\mathrm{T}$ antigen in regulation of DNA synthesis and the cell cycle. We introduced an antisense RNA plasmid into VA-13 cells and examined the morphology of the cells and the details of the cell cycle of the antisense transformants.

Cellular oncogenes and anti-oncogenes play an important role in the regulation of cellular proliferation and differentiation (42). In the present study, we focused upon the coordinated expression of the retinoblastomasusceptibility gene (RB1) and the SV40-T antigen. Inactivation of RB1 is correlated with the development of a subset of human neoplasias $(16,30,43)$. The product of the retinoblastoma gene is a nuclear protein, termed $\mathrm{pRB}$, with a molecular weight of $105-\mathrm{kDa}$. This protein can be phosphorylated to yield the phosphoprotein, p105-RB (ppRB) $(30,31,32,43)$. To date, three biochemical properties of $\mathrm{pRB}$ have been described. First, 
pRB can form specific complexes with oncoproteins of several DNA tumor viruses, such as adenovirus E1A protein, SV40 large $T$ antigen and papilloma virus 16 E7 protein $(9,12,13,14,25,31,36,45)$. Second, the expression of $\mathrm{pRB}$ varies with the progress of the cell cycle and the differentiation of cells, suggesting that modification, such as phosphorylation of $\mathrm{pRB}$, might play an important role in cell growth $(2,4,6,9,12,13,32,33)$. Only the unphosphorylated form of pRB binds to SV40 large $T$ antigen, an interaction that may contribute to the transforming activity of the viral oncoprotein $(8$, $31,32)$. Third, $p R B$ can regulate the transcriptional expression of $c$-fos $(38)$ and $c-m y c$ genes $(37,39)$.

Here we report that cells transformed with an antisense gene for SV40-T antigen were divided, for the most part, into two morphologically different groups (VA-AS5-8 and VA-AS37-8), in wihch the level of expression of SV40-T antigen was reduced by the introduction of the antisense gene for the SV40-T antigen. The characteristics of these cells were examined, with emphasis on the morphology of cells, the cell cycle and the expression of growth-related genes. Our results indicate that the SV40-T antigen may possibly play a fundamental role in the proliferation and immortalization of human diploid cells.

\section{MATERIALS AND METHODS}

Plasmid constructs. Plasmids carrying antisense and sense genes for the large $T$ antigen, pRSV-ASTag and pRSV-STag, were constructed as follows. DNA of cs1085 (11) was digested by $B a m \mathrm{HI}$ and $T a q \mathrm{I}$, and a $2.2-\mathrm{kb}$ DNA fragment containing the gene for $\mathrm{T}$ antigen was isolated. pRSVc-jun (28) was digested by HindIII and $\mathrm{HpaI}$ to generate a 3.3-kb DNA fragment which contained the Rous sarcoma virus long-terminal repeat (RSV-LTR) promoter and an SV40 polyadenylation site, and then it was blunt-ended by the Klenow large fragment of DNA polymerase I. Both DNA fragments were ligated to generate a pRSVTag expression plasmid with either the antisense orientation (pRSV-ASTag) or the sense orientation (pRSV-STag), relative to the LTR promoter (Fig. 1).

Cells and culture conditions. Normal human diploid WI38 cells and the SV40-transformed line of WI-38 cells (VA-13) were obtained from the Japanese Cancer Resources Bank

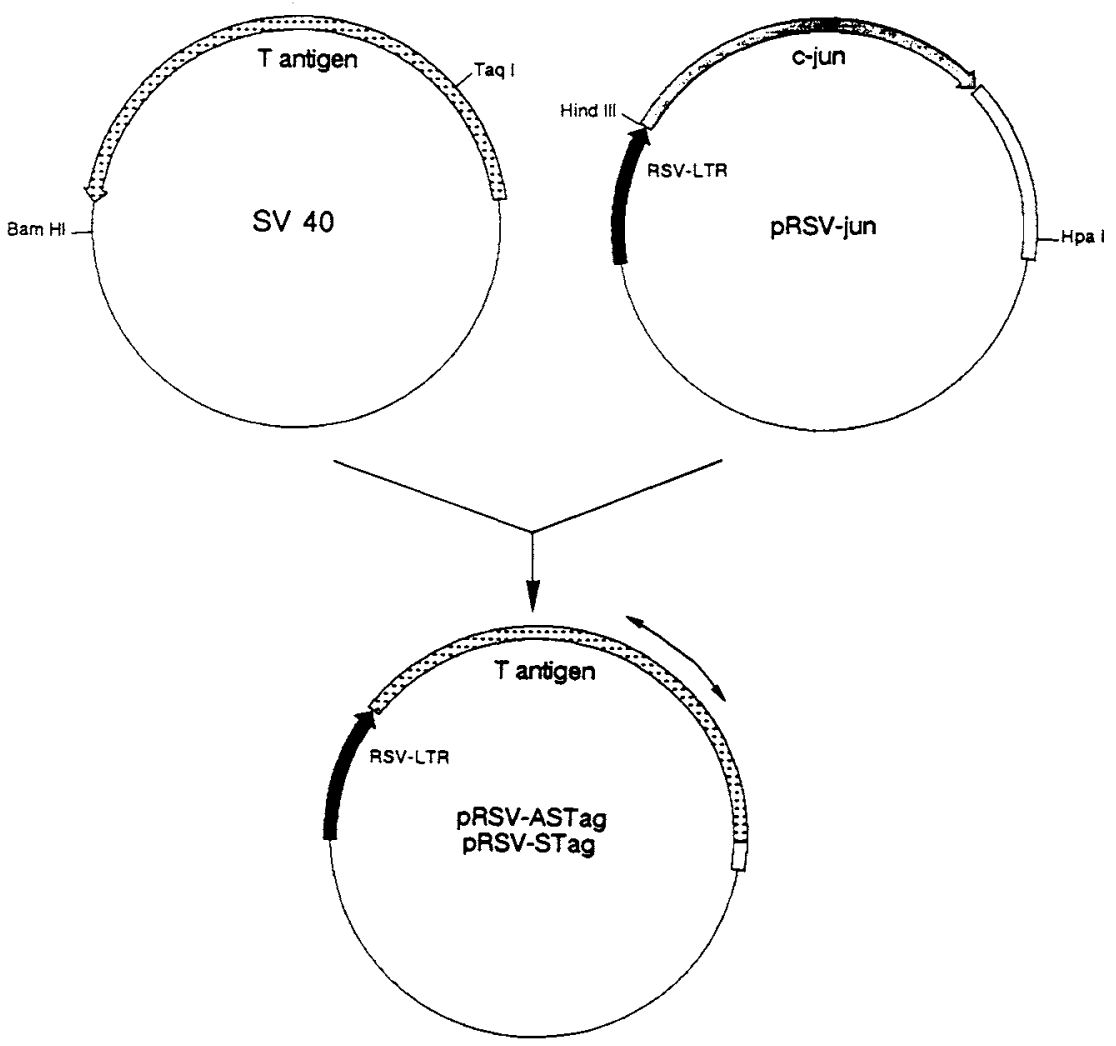

Fig. 1. Construction of plasmids pRSV-ASTag and pRSV-STag. Antisense and sense SV40-T antigen plasmids, pRSV-ASTag and pRSVSTag, were constructed as described in "MATERIALS AND METHODS". Dotted regions are the coding region of the gene for SV40-T antigen. Black and shaded arrows are the coding sequences of RSV-LTR and $c-j u n$, respectively. The open box is the polyadenylation site of SV40. pRSVASTag contained the gene for the SV40-T antigen in the antisense orientation relative to the LTR promoter, while pRSV-STag contained this gene in the sense orientation. 
(Tokyo). Both cell lines were grown in modified Eagle's Medium (MEM; Nissui, Tokyo) supplemented with $0.03 \%$ L-glutamine, $0.2 \% \mathrm{NaHCO}_{3}, 60 \mu \mathrm{g} / \mathrm{ml}$ kanamycin and $10 \%$ fetal bovine serum (FCS; Hyclone Lab. Inc., Logan, UT) for VA-13, or $20 \% \mathrm{FCS}$ for WI-38, in an incubator in $5 \% \mathrm{CO}_{2}$ in air. Labeling with $\left({ }^{35} \mathrm{~S}\right)$-methionine or $\left({ }^{32} \mathrm{P}\right)$-orthophosphate of the relevant cultures was achieved by incubating cells in serumfree, methionine-free (or phosphate-free) Dulbecco's modified Eagle's medium (DMEM; GIBCO, Grand Island, NY) supplemented with $\left({ }^{35} \mathrm{~S}\right)$-methionine $(0.165 \mathrm{mCi} / \mathrm{ml}, \sim 1,000$ $\mathrm{Ci} / \mathrm{mmol}$; Amersham Japan, Tokyo) or $\left({ }^{32} \mathrm{P}\right)$-orthophosphoric acid ( $1 \mathrm{mCi} / \mathrm{ml}$; Amersham Japan, Tokyo) for $3 \mathrm{hr}$ or $1 \mathrm{hr}$, respectively, as described by Ludow et al. (32) and Decapro et al. (8). After radiolabeling, the cells were lysed and the clarified supernatants were immunoprecipitated to identify the phosphorylated and nonphosphorylated forms of $\mathrm{pRB}$ and SV40-T proteins as described $(8,32)$.

$D N A$ transfection and selectin of antisense RNA transformants. The transfection was carried out by a slight modification of the method described by Wigler et al. (46). $15 \mu \mathrm{g}$ of pRSV-ASTag (or pRSV-STag) and $5 \mu \mathrm{g}$ of pRSVneo (19) were introduced into VA-13 by the calcium precipitation method $(26,46)$. After incubation for $4 \mathrm{hr}$, cells were exposed to $15 \%$ glycerol-Hanks buffered saline for $2 \mathrm{~min}$, washed twice with phosphate-buffered saline (PBS) and incubated in fresh MEM that contained $0.5 \mathrm{mg} / \mathrm{ml}$ of G418. The medium was changed every 3 days and the transfectants were selected about 17 days after transfection. Transfectants were harvested with trypsin, placed in 24-well plates in FCS-MEM without G418 and recloned as described elsewhere (48).

Immunoaffinity precipitation. Whole-cell extracts (100$150 \mu \mathrm{g})$ were incubated with a monoclonal antibody against large $\mathrm{T}$ antigen (pAb419, an $\mathrm{IgG}_{2}$ monoclonal antibody that reacts with SV40 T and small $t$ antigen) (22) or a monoclonal antibody against pRB (RB-PMG3-245, which reacts with $\mathrm{pRB} / \mathrm{pRB}^{\text {phoso}}$; Phar Migen, NY) $(8,31)$ or an antibody against the RB polypeptide (RB-Ab2; Oncogene Science Inc., Manhasset, NY) for $1 \mathrm{hr}$ at $4^{\circ} \mathrm{C}$ in a buffer that contained 20 mM HEPES (pH 7.9), $40 \mathrm{mM} \mathrm{KCl}, 1 \mathrm{mM} \mathrm{MgCl}_{2}, 0.1 \mathrm{mM}$ EGTA, $0.1 \mathrm{mM}$ EDTA, $0.5 \mathrm{mM}$ DTT and $3 \mathrm{mg} / \mathrm{ml} \mathrm{BSA}$. The mixtures were then further incubated with protein A-Sepharose beads (Pharmacia LKB, Uppsala, Sweden) for $1 \mathrm{hr}$ at $4^{\circ} \mathrm{C}$. The beads were centrifuged and washed four times with $800 \mu \mathrm{l}$ of the same buffer and then treated with $6 \mu \mathrm{l}$ of the buffer supplemented with $0.8 \%$ deoxycholate (Sigma, St. Louis, MO). The beads were centrifuged, and the supernatant was treated with SDS sample buffer and subjected to electrophoresis and Western blotting with monoclonal antibody against $\mathrm{pRB}$ or SV40-T.

Affinity chromatography. A whole-cell extract was prepared from cells ( $250 \mathrm{mg}$ of protein) and chromatographed on a heparin-agarose column as described previously (31). The material eluting at $600 \mathrm{mM} \mathrm{KCl}$ was diluted with 4 vol. of buffer [20 mM HEPES (pH 7.6), 10\% glycerol, $0.1 \mathrm{mM}$ EGTA, 0.1 mM DTT, $0.2 \mathrm{mM}$ PMSF]. This preparation was chromatographed on a 1-ml pAb419 (IgG fraction)-Sepharose $4 \mathrm{~B}$ affinity column. The column was washed with the same buffer supplemented with $100 \mathrm{mM} \mathrm{KCl}$ and then eluted with buffer that contained $1 \mathrm{M} \mathrm{KCl}$. Fractions of $1 \mathrm{ml}$ were collected.

Immunoblots of cell lysates. SDS-polyacrylamide gel electrophoresis (SDS-PAGE) on $8 \%$ gels was performed by the method of Laemmli (29). Approximately $10^{6}$ cells were lysed in $50 \mu \mathrm{l}$ of SDS sample buffer, denatured at $100^{\circ} \mathrm{C}$ for $5 \mathrm{~min}$ and centrifuged at $15,000 \mathrm{rpm}$ for $5 \mathrm{~min}$. The supernatant was subjected to electrophoresis. Western blots were performed by the protocol supplied with the Immuno-Blot assay kit (BioRad, Richmond, CA) with a slight modification. After SDSPAGE, proteins were transferred to a nitrocellulose membrane by the Sartoblot II system (Sartorius, Göttingen, FRG). The membranes were soaked in $6 \mathrm{M}$ urea for $10 \mathrm{~min}$, washed 4 times in water, soaked in a solution of $0.1 \mu \mathrm{g} / \mathrm{ml}$ of heparin in $10 \mathrm{mM} \mathrm{HCl}$ for $2 \mathrm{~min}$, washed in water 3 times, soaked in Block Ace (Dainihon Seiyaku, Osaka) for $30 \mathrm{~min}$ and washed twice in PBS. In some experiments, one membrane was reacted with pAb419 (22). Another membrane was reacted with a solution of $10 \mu \mathrm{g} / \mathrm{ml}$ pre-immunized mouse IgG as a negative control. In other experiments, the membrane was reacted with monoclonal or polyclonal antibody against $\mathrm{pRB}(8,31)$. The membranes were washed with $0.05 \%$ Tween 20 in PBS for $10 \mathrm{~min}$ twice, reacted with alkaline phosphatase-conjugated antibodies against mouse IgG (Bio-Rad) for $30 \mathrm{~min}$, washed with $0.05 \%$ Tween 20 in PBS for 10 min and finally incubated with $330 \mu \mathrm{g} / \mathrm{ml}$ nitroblue tetrazolium (Sigma) and $165 \mu \mathrm{g} / \mathrm{ml}$ 5-bromo-4-chloro-3-indolyl-phosphate (Sigma) in $100 \mathrm{mM}$ Tris (pH 9.5), $100 \mathrm{mM} \mathrm{NaCl}$ and $5 \mathrm{mM} \mathrm{MgCl}_{2}$ for 30 min. Color development was achieved with rabbit antibodies raised in rabbit against mouse antibodies and conjugated to alkaline phosphatase (Wako Chemical Co., Tokyo).

Analysis of RNA. Total cellular RNA, prepared by the guanidium isothiocyanate method (7), was fractionated on a $1.2 \%$ agarose gel that contained $6 \%$ formaldehyde and transferred to a Hybond-N filter (Amersham) as described elsewhere (41). filters were hybridized under high-stringency conditions with riboprobes obtained after transcription in vitro of the 10.5-kb Nde1 fragment of the gene for the SV40-T antigen subcloned into Bluescript SKII- (Stratagene, La Jolla, CA). Antisense and sense RNA probes were generated by T7 and T3 RNA polymerases, respectively. The 1.7-kb Ncol$B s m 1$ fragment of the gene for pRB (25) was prepared and radiolabeled with $\left({ }^{32} \mathrm{P}\right)-\alpha$-dCTP by random priming, as described elsewhere (15). The filters were prehybridized for $5 \mathrm{hr}$ and hybridized with $\left({ }^{32} \mathrm{P}\right)$-labeled probe for $20 \mathrm{hr}$ at $42^{\circ} \mathrm{C}$ in 6 $\times$ SSC $(1 \times$ SSC: $150 \mathrm{mM} \mathrm{NaCl}, 15 \mathrm{mM}$ sodium citrate, $\mathrm{pH}$ 7.0), $0.5 \%$ SDS, $5 \times$ Denhardt's solution, $50 \mathrm{mM}$ EDTA and $100 \mu \mathrm{g} / \mathrm{ml}$ denatured salmon sperm DNA. Filters were washed several times at $65^{\circ} \mathrm{C}$ in $0.2 \times \mathrm{SSC}$ and $0.1 \% \mathrm{SDS}$, and then they were exposed to RX-film (Fuji, Yokohama) at $-80^{\circ} \mathrm{C}$ under an intensifying screen.

Synchronization of cells and growth rates. Cells were tryp- 
sinized, transferred to methoionine-free or phosphate-free MEM that contained $1 \%$ dialyzed bovine fetal serum (GIBCO), seeded at a density of $5 \times 10^{5}$ cells/dish and incubated at $37^{\circ} \mathrm{C}$ for $48 \mathrm{hr}$. At this time, the cells were found to be arrested in the $G_{1}$ phase. The cells were then washed three times with methionine or phosphate-free DMEM that contained $10 \%$ FCS and $0.5 \mathrm{mM}$ hydroxyurea (Sigma), which led to growth arrest at $\mathrm{G}_{1 / \mathrm{s}}$. The plates were then washed three more times with serum-free DMEM and incubated for an additional $1.5 \mathrm{hr}$ in DMEM that contained 10\% FCS. After $48 \mathrm{hr}$ of cultivation, cells were metabolically radiolabeled with $\left({ }^{35} \mathrm{~S}\right)$ methionine $(5 \mathrm{mCi} / 10 \mathrm{ml})$ for $3 \mathrm{hr}$ or with $\left({ }^{32} \mathrm{P}\right)$-phosphoric acid $(5 \mathrm{mCi} / 10 \mathrm{ml})$ for $1 \mathrm{hr}$ and then lysed. Immunoprecipitation was then performed as described above. In order to measure the growth rate of cells, $5 \times 10^{3}$ cells (VA-13, VA-AS5-8, VA-S26) and $2 \times 10^{3}$ cells (WI-38) were seeded per dish $(3.5$ $\mathrm{cm}$ in diameter). The cells were counted at appropriate times and the ratios of the number of cells relative to the number at inoculation were calculated. The progress of the cell cycle was followed by monitoring the DNA content by cytofluorometry as described elsewhere (10).

Labeling with BrdU and analysis by flow cytometry. Labeling of cells in the $S$ phase and staining with propidium iodide (PI; Sigma) were performed essentially by the methods of Delbeare et al. (10). 5-Bromo 2'-deoxyuridine (BrdU, Sigma) was added to cells at $10 \mu \mathrm{M}$. After a 30 -min incubation, cells were trypsinized, washed with PBS and fixed in 70\% ethanol for $30 \mathrm{~min}$ on ice. Cells were collected by centrifugation at $3,000 \mathrm{rpm}$ for $5 \mathrm{~min}$ and resuspended in PBS. Cells $\left(2 \times 10^{6}\right)$ were centrifuged at $4,000 \mathrm{rpm}$ for $3 \mathrm{~min}$ and cell pellets were suspended in $0.5 \mathrm{ml}$ of $0.1 \mathrm{~N} \mathrm{HCl}$ and left for $10 \mathrm{~min}$. Then $0.5 \mathrm{ml}$ of $4 \mathrm{~N} \mathrm{HCl}$ was added and cells were left for another $30 \mathrm{~min}$. Cells were centrifuged and suspended in $1 \mathrm{ml}$ of $0.1 \mathrm{M}$ sodium borate buffer ( $\mathrm{pH} 8.5$ ). After washing, cell pellets were resuspended in $50 \mu \mathrm{l}$ of $0.5 \%$ Tween 20 in PBS and $20 \mu \mathrm{l}$ of a solution of BrdU-specific monoclonal antibody were added (Becton Dickinson, Mountain View, CA) was added. After $30 \mathrm{~min}$ at room temperature and centrifugation, cells pellets were suspended in $50 \mu 1$ of $0.5 \%$ Tween 20 in PBS and $1 \mu \mathrm{l}$ of a solution of FITC-conjugated antibodies against mouse IgG (Zymed, San Francisco, CA) was added. After 30 min at room temperature cell pellets were washed again by centrifugation. Finally, cell pellets were resuspended in a solution of $10 \mu \mathrm{g} / \mathrm{ml} \mathrm{PI}$ in PBS, left on ice for more than $20 \mathrm{~min}$ and subjected to analysis by FACStar (Becton Dickinson). Excitation was at $488 \mathrm{~nm}$. FITC and PI were monitored at $530 \mathrm{~nm}$ and $620 \mathrm{~nm}$, respectively.

\section{RESULTS}

Morphological changes in antisense transformants. WI-38 is a line of normal human diploid fibroblast cells. While the cells are in early passage, the directions of the fibers are almost uniform (Fig. 2b). After a definite number of divisions the ability of cells to proliferate is great- ly reduced and cells extend long slender protrusions (arrowheads), expand their narrow folds (arrows) and the area of attachment to the substratum becomes very wide (Fig. 2c). These morphological changes are typical of aged cells and they can be explained by reductions in levels of hyaluronate and chondroitin sulfate components and increases in levels of heparan sulfate on the cell surface (34). VA-13 (Fig. 2a) is a line of the immortalized cells which was isolated after transformation of WI-38 with SV40 virus. The cells are round and have smaller areas of attachment to the substratum than those of WI-38 cells (Fig. 2b).

Antisense $\mathrm{T}$ transformants showed reduced expression of SV40-T antigen and formed smaller colonies. We obtained a large number of antisense transformants and were able to divide them into two morphologically different types. Two transformants (VA-AS5 and VAAS37) were seeded in dishes at extremely low density. After colonies had grown up, seven colonies were reselected (VA-AS5-7, -8, -9, -10, and VA-AS37-8, -9, -12), trypsinized and replated in 24-well plates. VA-AS5-7 and VA-AS5-10 almost ceased to proliferate after continued cultivation so they could not be used for further studies. Two morphologically different subclones, VAAS5-8 (Fig. 2e) and VA-AS37-8 (Fig. 2f), retained reduced proliferative capacity and exhibited morphological changes similar to those of WI-38 after cultivation for more than 3 months. About $20 \%$ of VA-AS5-8 cells had narrow folds (arrows) and wide areas of attachment (arrowheads), and most of the VA-AS37-8 cells extended slender protrusions (arrowheads) while some of them also had narrow folds. Thus, with respect to morphology, two different transformants seemed to have reverted partially to the senescent WI-38 phenotype, possibly as a result of the introduction of the antisense gene for the SV40-T antigen. As a transfectant with the sense gene for the SV40-T antigen, clone VA-S26 had the same morphology as VA-13 (Fig. 2d). The morphology of the transfectant VA-AS53 (Fig. 2g) was intermediate between that of senescing WI-38 cells (Fig. 2c) and immortalized VA-13 cells (Fig. 2a). The VA-AS53 transfectant was the best candidate among antisense clones for a comparison of the molecular and morphological characteristics of senescent cells and immortalized cells. However, during these studies, the cells unfortunately reverted to the phenotype of the original VA-13 cells, perhaps because of the unstable expression of the antisense gene for the SV40-T antigen during the analysis.

Growth rates. Figure 3 shows the growth curves of parental cells and antisense transformants. VA-S26, which was selected because it formed the largest colonies, had a growth rate similar to that of VA-13. The doubling time of each cell line was measured after synchronization of cell growth by serum starvation and treatment with hydroxyurea $(6,10)$. The doubling times 
a

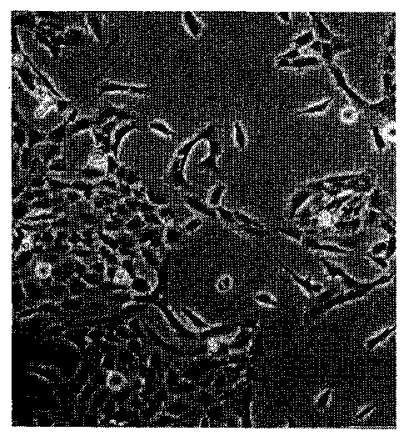

e

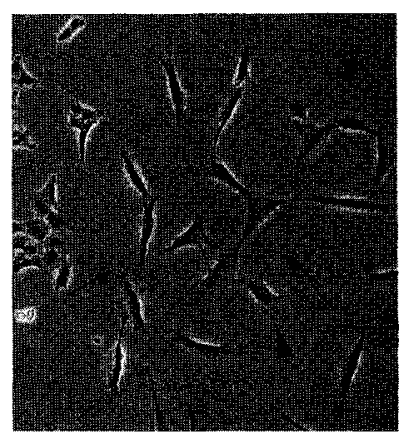

b

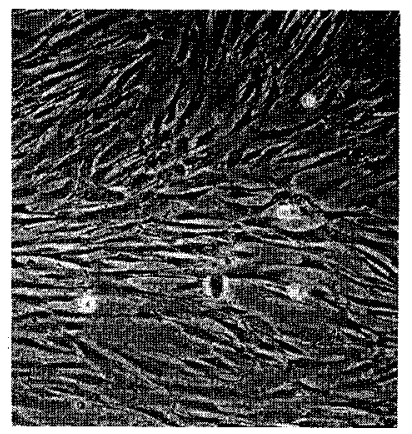

f

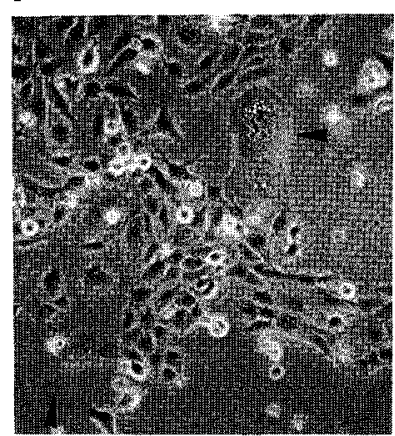

C

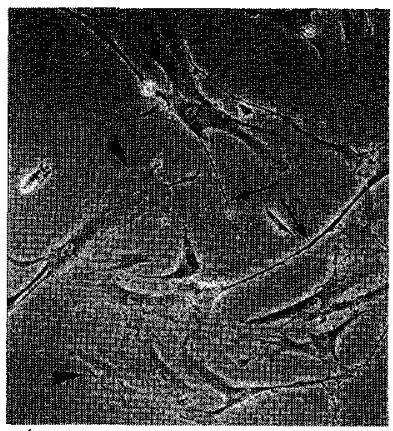

$\mathrm{g}^{*}$

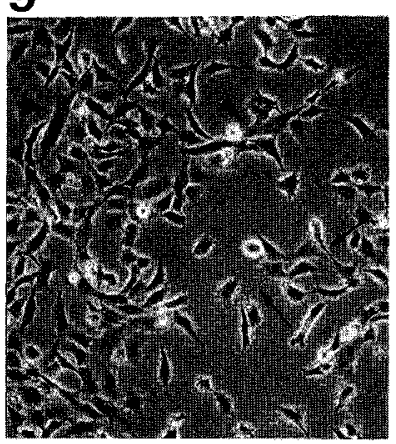

d

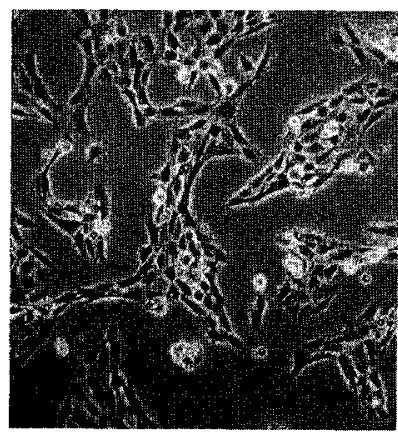

Fig. 2. Morphology of WI-38, VA-13 and antisense transformants. Phase-contrast micrography of VA-13 (a), early-passage WI-38 (b), senescent WI-38 (c), VA-S26 (d), VA-AS5-8 (e) and VA-AS37-8 (f) and VA-AS53 (g) cells. The narrow folds, wide areas of cell contact (indicated by arrowheads, $\mathbf{\Delta}$ ) and the slender protrusions of cells (indicated by arrows, $\uparrow$ ) are typical of aged cells. The scale bar represents $100 \mu \mathrm{m}$.

of VA-13 and VA-S26 were approximately $25 \mathrm{hr}$ and 20 hr, respectively (Table I). The doubling time of WI-38 was $52 \mathrm{hr}$. Two antisense transformants, VA-AS5-8 and VA-AS37-8, had lower growth rates which were similar to that of WI-38 (Fig. 3), and their doubling times were about $46 \mathrm{hr}$ and $44 \mathrm{hr}$, respectively (Table I). From these results, it seems that the inhibition of synthesis of the SV40-T antigen may cause a substantial alteration in the growth machinery of the cells.

Cell cycle analysis by flow cytometry. The cell cycles of two transformants (VA-AS5-8 and VA-AS37-8) were longer than that of VA-13 (Fig. 4A). After doublestaining of both antisense transformants with BrdU and PI, flow cytometry was performed to examine the progress of the cell cycle. For each population of cells three phases could be identified. In two cell lines VA-13 and VA-S26, which showed rapid cell growth, the ratio of cells, in the $\mathrm{G}_{1 / 0}, \mathrm{G}_{2 / \mathrm{M}}$ and $\mathrm{S}$ phases was about $33: 28$ : 39 (Fig. 4B). In VA-AS5-8, the ratio was $48: 32: 20$ (Fig. 4B); the population of cells in the $S$ phase was smaller and the populations in the $G_{1 / 0}$ and $G_{2 / M}$ phases were larger than in the case of VA-13 or VA-S26. In another subline, VA-AS37-8, the ratio was $54: 20: 26$ (Fig. 4B) and the populations of cells in the $G_{1 / 0}$ and $\mathrm{G}_{2 / \mathrm{M}}$ phases were also larger than in the case of the par-

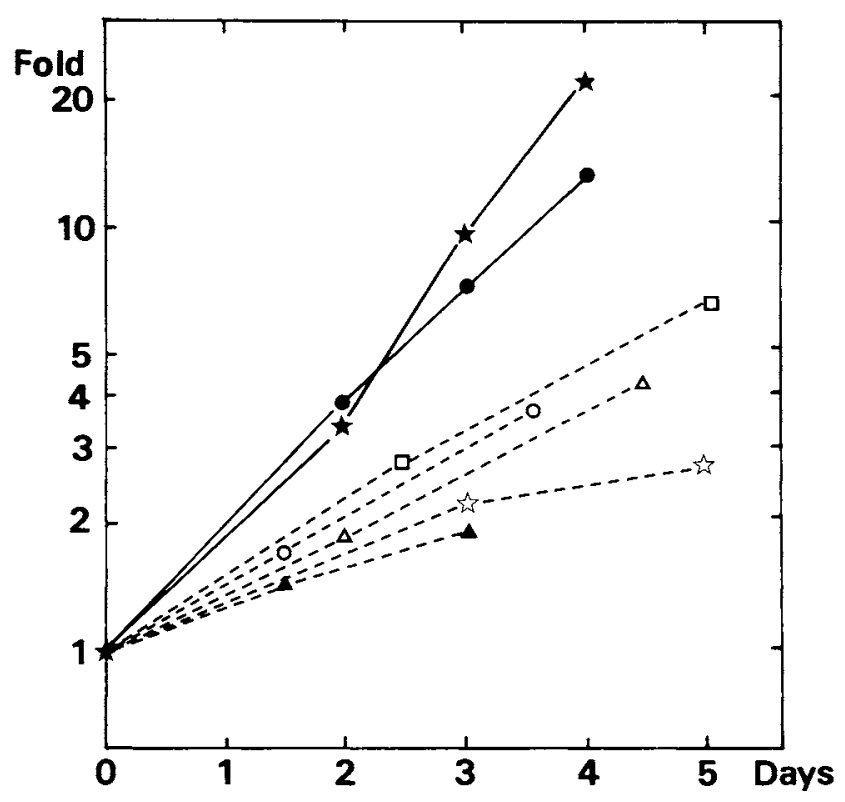

Fig. 3. Cell growth. Relative increases in cell number are plotted semilogarithmically. VA-13 $\bullet$ ), VA-S26 $(\star)$, VA-AS5-8 (O), VAAS37-8 ( $\square)$, VA-AS53 (4), early passage WI-38 $(\triangle)$ and aged WI-38 (统). 
Table I. Summary of the PROPERTIES OF tHe CELl LINES AND TRANSFORMants.

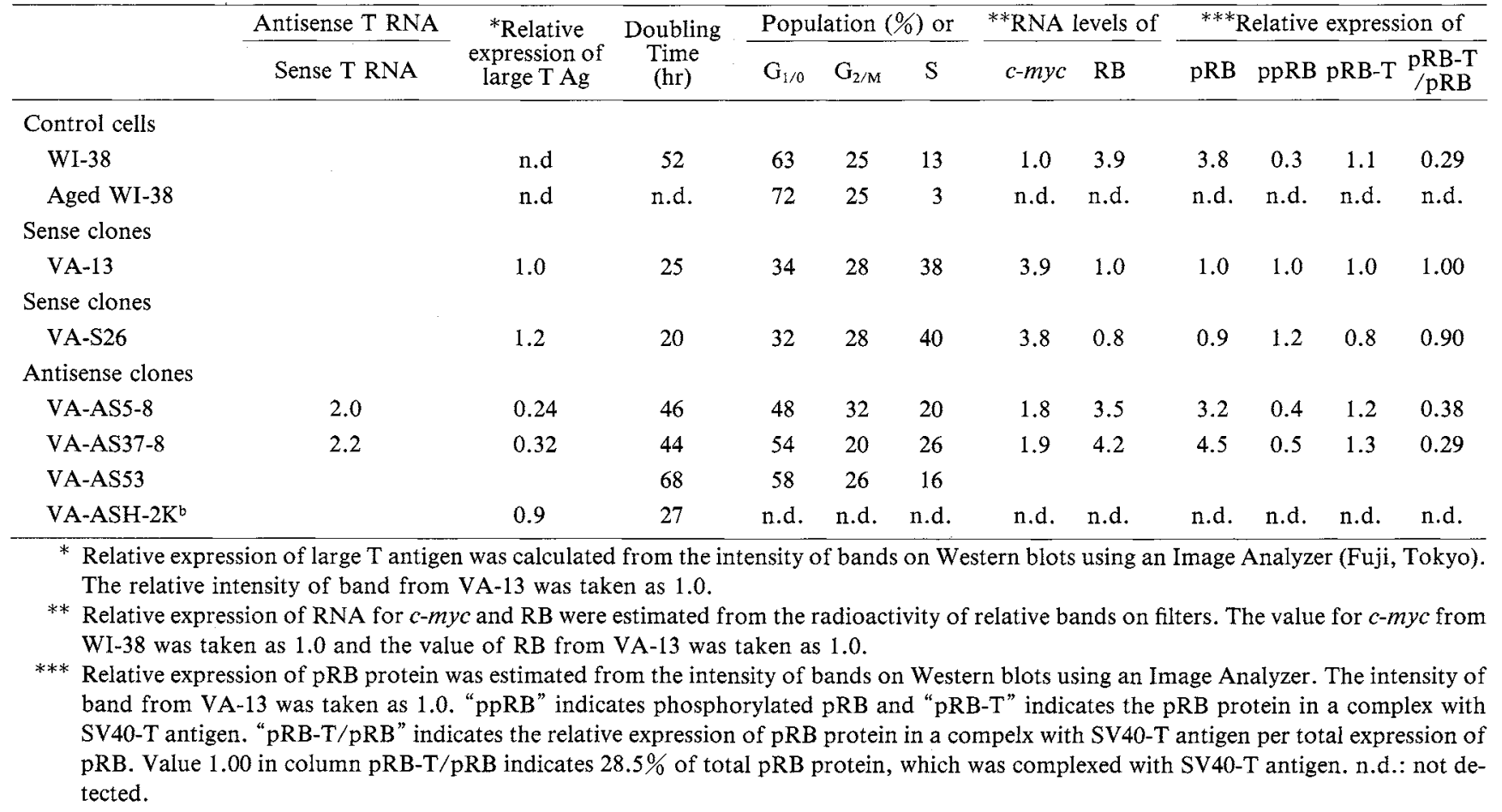

ent VA-13 cells.

Expression of the large $T$ antigen. Figure 5 shows the results of Western blotting with the monoclonal antibody pAb419, which was used to examine the expression of the SV40-T antigen in each transformant. The SV40-T antigen was detected as a $94-\mathrm{kD}$ a protein except in the case of WI-38 (Panel B, lane 1). In both VA-13 (Panel B, lane 2) and VA-S26 (Panel B, lane 5) cells, the SV40-T antigen was expressed at significant levels. The level of expression of the SV40-T antigen was greatly reduced in VA-AS5-8 (Panel B, lane 3) and in VA-AS37-8 (Panel B, lane 4). When pre-immune mouse IgG was used in place of pAb419, as a negative control, no specific bands were stained (data not shown). The level of $\beta_{2}$-microglobulin (12-kDa) was nearly constant (Panel C). Thus, the antisense SV40-T transformants showed a significant reduction (of about $70 \%$ ) in the level of large $\mathrm{T}$ antigen as compared to control clones.

Expression of the $R B$ protein. Since it is generally accepted that SV40-T antigen binds only the unphosphorylated form of $\mathrm{pRB}(31,32)$, it seems possible that unphosphorylated $\mathrm{pRB}$ might inhibit entry into the $\mathrm{S}$ phase and that such inhibition could be relieved by either phosphorylation or binding to SV40-T antigen. To test this hypothesis, we analyzed the total amounts of $\mathrm{pRB}$ in antisense transformants and the amounts of pRB that bound to SV40-T antigen. We also analyzed the phosphorylation profile of pRB proteins in antisense transformants after synchronization, as described above. The levels of the 105-kDa pRB, in both antisense transformants (Fig. 6B, lanes 3, 4) were 3- to 4-fold higher than those in VA-13 and VA-S26 (lanes 1, 5). The level of $\beta_{2}$-microglobulin was almost constant (Fig. $6 \mathrm{C}$ ). These levels of pRB were compatible with those of mRNA transcribed from the RB gene (data not shown). Whole-cell extracts of each line of cells were fractionated on a heparin-agarose column with subsequent affinity chromatography on a column with anti-IgG against SV40-T. The bound fractions from the affinity column were pooled and subjected to SDS-PAGE for Western blotting with the pRB-specific antibody. As can be seen in Figures $6 \mathrm{E}$ and $\mathrm{F}$, the $105-\mathrm{kDa}$ pRB polypeptide, as detected by the pRB-specific antibody, is indeed present in the eluate from the affinity column, coinciding with the presence of the SV40-T-pRB complex. In VA-AS5-8 and VA-AS37-8, the level of expression of pRB complexed with the SV40-T antigen was greatly reduced (Figs. 6B, F; see column "pRB-T/pRB" in Table I). However, the levels of the complexed pRB in VA-13 and VA-S26 (lanes 1, 5) were not significantly altered

Fig. 4. Fluorocytometric study of VA-13 (a), early-passage WI-38 (b), senescent WI-38 (c), VA-S26 (d), VA-AS5-8 (e), VA-AS37-8 (f), and VA-AS53 (g) cells. Panel A: Fluorescence of FITC is shown on the X axis and fluorescence of PI is shown on the $\mathrm{Y}$ axis. Cell frequency is given on the $\mathrm{Z}$ axis and is shown at $10 \%$ contour intervals. Horizontal and vertical markers were set to partition cells at $\mathrm{G}_{1 / 0}$ (lower left), $\mathrm{G}_{2 / \mathrm{M}}$ (upper left) and S (right) phases. Panel B: Table summarizes the percentages of cells in the three phases for each cell line. 
Repression Induced by Antisense SV40-T Antigen Gene

A
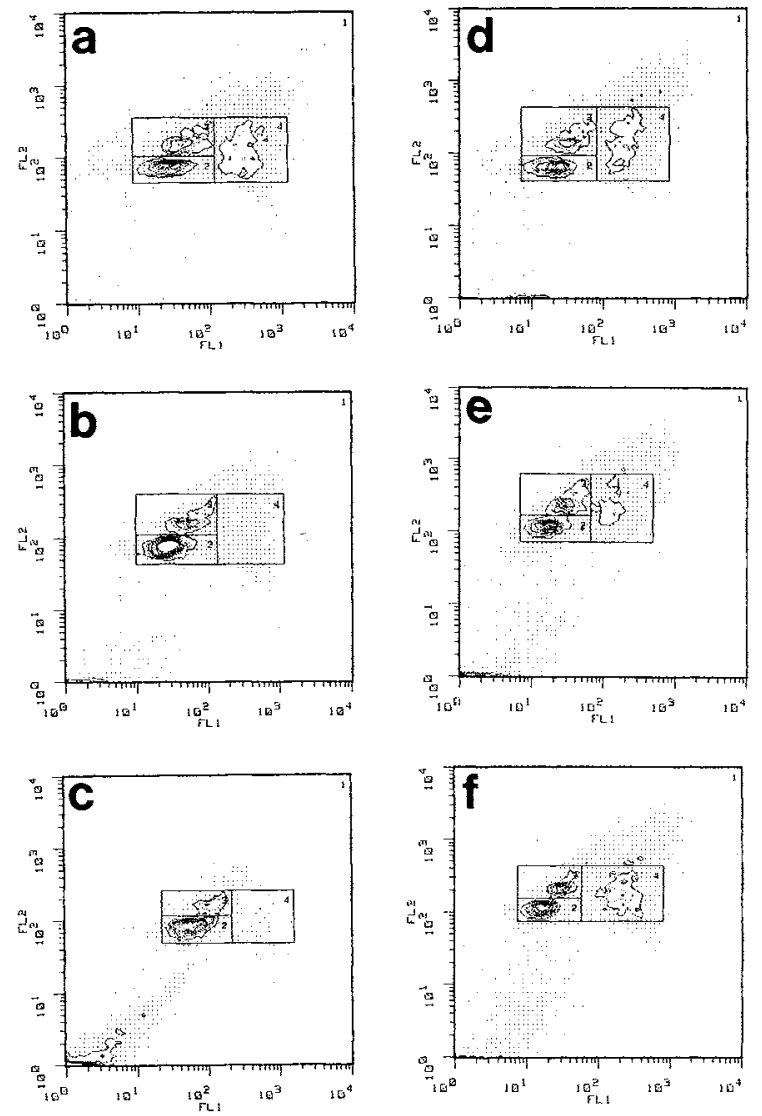

B

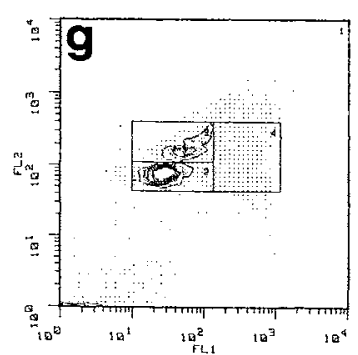

\begin{tabular}{|c|c|c|c|c|}
\hline & & $\mathrm{G}_{1 / \mathrm{a}}$ & $\mathrm{G}_{2 / M}$ & $\mathrm{~S}$ \\
\hline a. & $V A-13$ & 34 & 28 & 38 \\
\hline b. & $w 1-38$ & 63 & 25 & 12 \\
\hline c. & Senescent $W 1-38$ & 72 & 25 & 3 \\
\hline d. & VA- $\$ 26$ & 32 & 28 & 40 \\
\hline e. & VA-AS5-8 & 48 & 32 & 20 \\
\hline f. & $V A-A S 37-8$ & 54 & 20 & 26 \\
\hline g. & VA-AS53 & 58 & 26 & 16 \\
\hline
\end{tabular}

Fig. 4. 

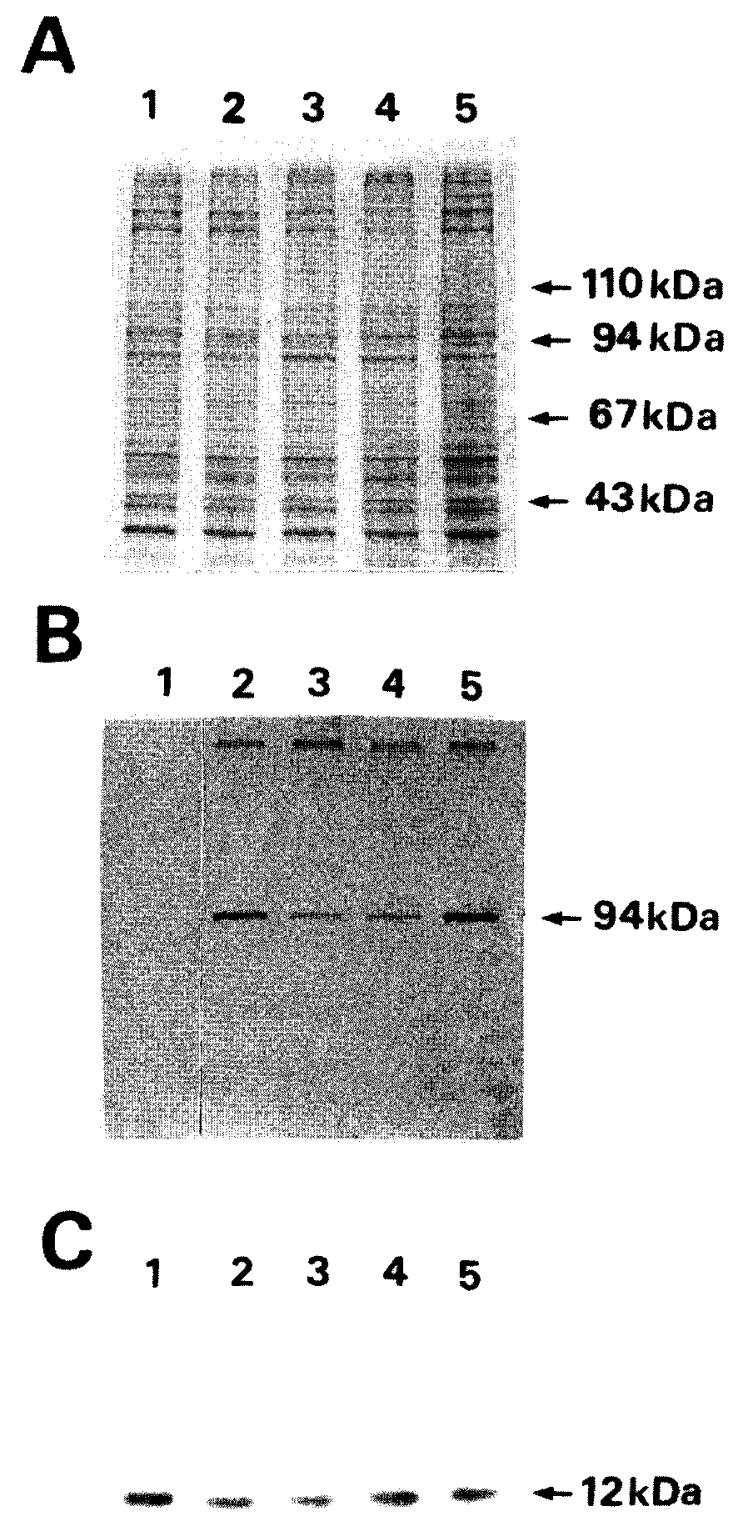

Fig. 5. Western blot analysis of SV40-T antigen. Panel A: Staining of proteins on the gel with Coomassie Brilliant Blue. Panel B: Western blotting using a monoclonal antibody specific for SV40-T antigen. Panel C: Western blotting using a monoclonal antibody specific for human $\beta_{2}$-microglobulin (a gift from Dr. Keiichi Itakura, City of Hope Institute, Duarte, CA). Lanes 1, 2, 3, 4, and 5: WI-38, VA-13, VA-AS5-8, VA-AS37-8 and VA-S26, respectively.

(Figs. 6B, F and Table I). The eluate from an affinity column prepared with antibodies against $c$-Jun did not contain pRB (Fig. 6G). Previous experiments have shown that, in extracts of synchronously growing cells, there exists a mixture of the phosphorylated and underphosphorylated forms of $\mathrm{pRB}$, which can be resolved by SDS-PAGE since the phosphorylated forms of the pro- tein migrate more slowly than the underphosphorylated protein $(4,6,9,33)$. It is apparent from the analysis shown in Figure 6D that the extracts from VA-13 and VA-S26 cells contained several species that reacted with the pRB-specific antibody (lanes 1,5), whereas extracts of antisense tranformants appeared to contain a single polypeptide (lanes 3,4 ). The polypeptide in the eluate from the SV40-T affinity column corresponds to the most rapidly migrating species of $\mathrm{pRB}$ in the whole-cell extract (Fig. 6F). Thus, the SV40-T antigen is in a complex with the unphosphorylated or underphosphorylated forms of $\mathrm{pRB}$.

Expression of the antisense gene for T antigen. Antisense RNAs from both transformants, VA-AS5-8 and VA-AS37-8, were detected as 2.2-kb RNAs and sense RNAs were detected as $2.5-\mathrm{kb}$ RNAs. The relative ratio of antisense RNA to sense RNA was calculated from the radioactivity of bands, as described elsewhere (12, 14), and the results are summarized in Table $I$. The level of expression of antisense gene for SV40-T is about twice that of the sense gene for SV40-T in terms of the respective mRNAs.

\section{DISCUSSION}

SV40 large $T$ antigen can confer immortality on eukaryotic diploid cells and it also induces malignancy as a result of its multifunctional activities, such as transactivation of ribosomal genes and induction of DNA synthesis in host cells (3). To elucidate the roles of SV40-T antigen in the immortalized cell line VA-13, we introduced an antisense SV40-T antigen expression plasmid into VA-13. Two different types of transformant (VAAS5-8 and VA-AS37-8) were obtained. Table I summarizes the characteristics of two antisense transformants, control cells (VA-S26) and parental cells (WI-38 and VA-13). The levels of expression of endogenous SV40-T antigen were correlated with the extent of perturbation of the cell cycle of the respective clones. It appears that the expression of antisense RNA for the SV40-T antigen reduced the level of expression of the SV40-T antigen (Fig. 5). The reduced amount of SV40-T antigen resulted in the elongation of the doubling time, which approached that of WI-38 (Fig. 3 and Table I). It was clear that $20 \%$ of the population of VA-AS5-8, which had a morphology similar to that of senescent WI-38 cells (Fig. 2c), was at $\mathrm{G}_{1 / 0}$. The apparent prolongation of the doubling time of VA-AS37-8 was also, for the most part, the result of the elongation of the $G_{1 / 0}$ phase and indicates a reduction in the rate of DNA replication (Table I). Iguchi-Ariga et al. (24) reported that $c-m y c$ protein may be involved in DNA synthesis. The levels of $c-m y c$ mRNA from antisense $\mathrm{T}$ transformants were approximately two-fold lower than that in VA-13 (Table I). 


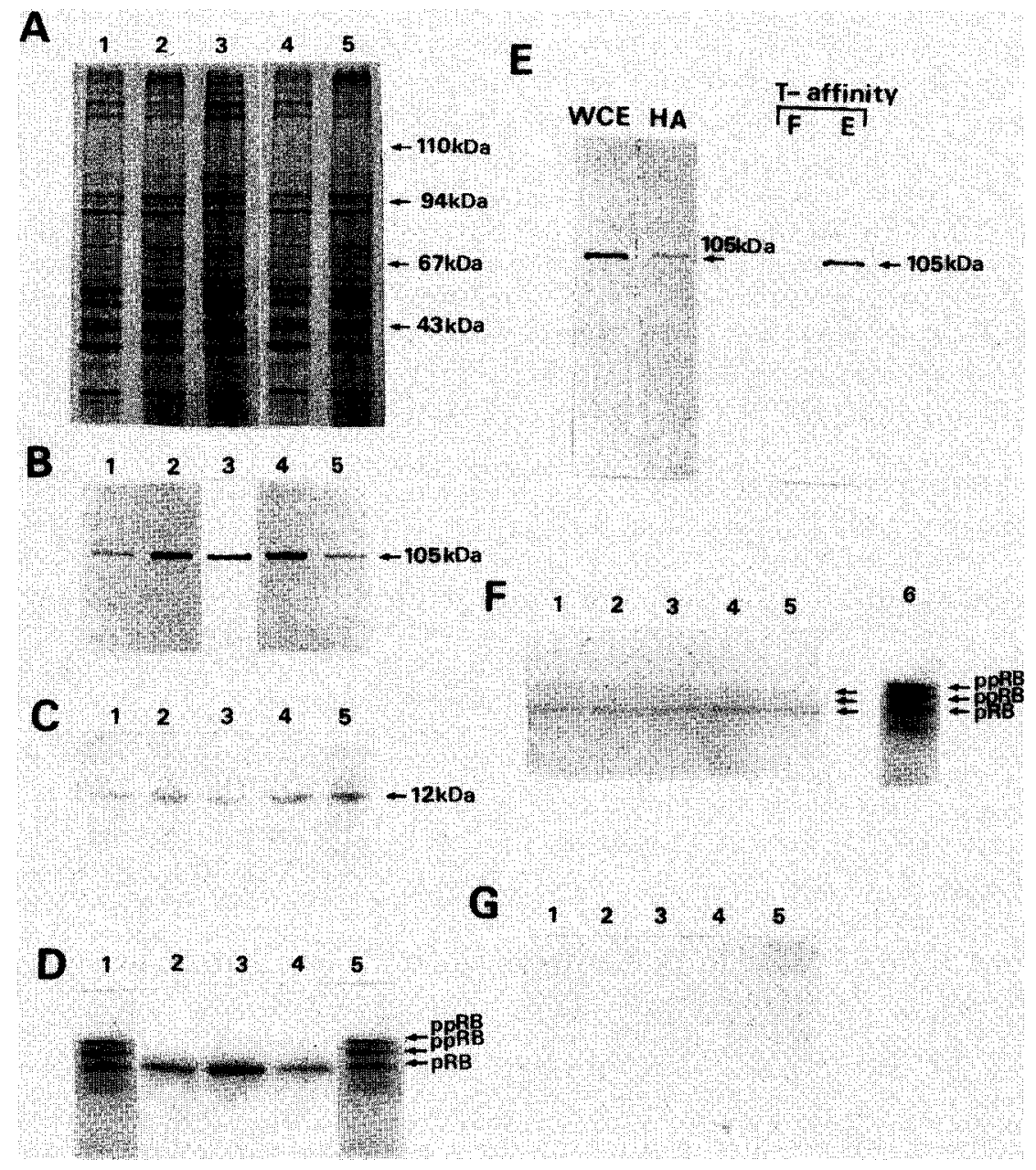

Fig. 6. Expression of RB protein. Panel A: Samples of various whole-cell extracts were dissolved in SDS-sample buffer and subjected to SDSPAGE (8\%) gel. $30 \mu \mathrm{l}$-aliquots of the whole-cell extracts were applied to the gel that was stained with Coomassie Brilliant Blue. Panel B: After electrophoresis, the separated polypeptides were electrophoretically transferred to nitrocellulose. The blot was incubated with pRB polypeptidespecific antiserum at $10 \mu \mathrm{g} / \mathrm{ml}$ and then with horseradish peroxidase-conjugated protein A. Panel C: The Western blots were carried out as described in the legends to Panels A and B. The same amounts of proteins (10 $\mu \mathrm{g}$ per lane) were applied to the gel. The blot was incubated with $\beta_{2}-$ microglobulin-specific antiserum and stained as described above. Panel D: Cultures of various cells were synchronized once and incubated for 48 $\mathrm{hr}$ as described in "MATERIALS AND METHODS". After cultivation for $48 \mathrm{hr}$, cell lysates were immunoprecipitated, solubilized and analyzed by SDS-PAGE $(6 \%)$ to resolve the phosphorylated polypeptides as described in the legend above. ppRB indicates the phosphorylated form of pRB. The concentrations of proteins in lanes 1 and 5 of Fig. 6D were two-fold higher than those in other lanes in the same panel (2.0 $\mu \mathrm{g}$ protein). Lanes 1, 2, 3, 4 and 5: VA-13, WI-38, VA-AS5-8, VA-AS37-8 and VA-S26, respectively. Panel E: The whole-cell extracts (WCE) from various cells were processed as described in "MATERIALS AND METHODS" and applied to the anti-SV40-T affinity column. Here, the column eluates from VA-AS5-8 were collected, precipitated with TCA, dissolved in SDS sample buffer and subjected to SDS-PAGE. After electrophoresis, the separated polypeptides were electrohoretically transferred to nitrocellulose and stained with pRB-specific antiserum. Because of the high concentration of protein in the material (HA) loaded on the affinity column as well as in the flow-through fraction (F), only $10 \%$ of the volume of these fraction was applied to the gel. Panel F: The Western blots of eluates through the affinity column were carried out as described in the legends to Panels D and E. ppRB indicates the phosphorylated form of pRB. The concentrations of proteins in lanes 3 and 4 of Fig. $6 \mathrm{~F}$ were two-fold higher than those in other lanes in the same panel (20 $\mu$ g protein). Lane 6 in Fig. 6F is a Western blot of WCE from VA-13. Panel G: Expression of pRB in the eluate from an anti-c-jun affinity column. The procedure was the same as in Panel $\mathrm{C}$ with the exception that an antiserum against $c-j u n$ was used to prepare the affinity column. Molecular weights were calculated from the positions of stained marker-proteins. Lanes 1, 2, 3, 4, 5 and 6: VA-13, WI-38 clones transfected with pRSV-STag, VA-AS5-8, VA-AS37-8, VA-S26 and WCE from VA-13, respectively.

We cannot exclude the possibility that the morphological changes in the two transformants were the results of spontaneous reversion of VA-13 to a phenotype with a decreased level of mRNA for the $T$ antigen. We obtained two transformed clones among $5 \times 10^{4}$ neomycin-resistant clones. The ratio for transformation was 
about 1 in $4 \times 10^{6}$, a value that is very much higher than the spontaneous mutation rate. The rate of spontaneous reversion of VA-13 is less than 1 in $3 \times 10^{8}(17)$. Thus, it is unlikely that these transfectants were generated by a reversion event. Furthermore, the control experiments, in which cells were transfected with antisense $\mathrm{H}-2 \mathrm{~K}^{\mathrm{b}}$ (VA-ASH-2 $\mathrm{K}^{\mathrm{b}}$ ), resulted in no reduction in synthesis of SV40-T antigen. These results indicate that the inhibition is highly sequence-specific.

The antisense RNA method, using the gene for the SV40-T antigen as described here, provides us with an experimental system for studying the mechanisms of switching from senescence to transformation and vice versa. Two of our transformants (VA-AS5-8, VAAS37-8) have properties intermediate between those of senescent WI-38 cells and transformed VA-13 cells, with respect to cell morphology, growth rate, expression of SV40-T antigen and perturbation of the cell cycle. VA-AS53 had a phenotype and molecular characteristics similar to those of senescent WI-38 cells. However, it was not characterized in detail because of cell death during cultivation.

Transforming proteins of several unrelated DNA tumor viruses, including the SV40-T antigen, have been shown to bind $\mathrm{pRB}$ in vitro $(9,12,14,36,45)$. In addition, it has been demonstrated that the SV40-T antigen binds exclusively to the unphosphorylated form of $\mathrm{pRB}$ $(4,6,9,33)$. This observation suggests that underphosphorylated $\mathrm{pRB}$ performs those aspects of the growthsuppressor functions of pRB that are susceptible to perturbation by SV40-T antigen. We found that the levels of expression of pRB in VA-AS5-8 and VA-AS37-8 were more than three-fold higher than in VA-13 and VA-S26 (Fig. 6B and Table I). However, the level of the complex between pRB and SV40-T antigen was greatly reduced in the antisense clones, as demonstrated by Western blotting of eluates from the anti-SV40-T affinity column (Figs. 6E, F and Table I). From the relative intensities of bands of $\mathrm{pRB}$ on Western blots, adjusted for the total concentration of protein and the number of cells, we estimated roughly that about $8 \%$ of $\mathrm{pRB}$ in the extracts from antisense transformants bound to the SV40-T antigen, in contrast, $28.5 \%$ of pRB in the extracts of VA-13 bound to the SV40-T antigen. It has been reported that senescent human fibroblasts contain the underphosphorylated form of $\mathrm{pRB}$ (40). After stimulation with serum, the cells can enter the $S$ phase and, during this stage, pRB can be phosphorylated. Thus, the phosphorylation of $\mathrm{pRB}$ to generate (ppRB) may be an immediate early event that triggers entry into the $S$ phase of senescent human fibroblasts $(4,9)$. The phosphorylation profile of the RB proteins in antisense clones showed that the majority of pRB was in the underphosphorylated form, in contrast to the case in VA13 cells where the under- and phosphorylated forms of
pRB predominated (Figs. 6C, E). From these observations, together with the evidence that $\mathrm{pRB}$ plays a role in suppression of growth, it is proposed that the interaction of SV40-T antigen with $\mathrm{pRB}$ results in inactivation of $p R B$ function and that unphosphorylated $p R B$ inhibits entry into the $S$ phase.

Our results indicate that the expression of $\mathrm{pRB}$, the formation of the complex with SV40-T and the phosphorylation of $\mathrm{pRB}$ coincide to a significant extent with the level of expression of SV40-T antigen. Recently, it was shown that $\mathrm{pRB}$ can interact with various proteins that are involved in the regulation of cell cycle, such as cyclin A (2), E2F $(1,5,35,47)$ and numbers of the myc family (39). This observation suggests the possibility that the expression of $\mathrm{pRB}$ is related to the proliferation of cells and, in particular, to the cell cycle. The antisense gene for the SV40-T antigen can reduce the level of expression of the SV40-T antigen, which directly or indirectly results in reduced or null expression of SV40T-pRB complexes. As a result, the cells may be converted from the proliferative to the senescent phenotype.

Acknowledgements. We thank Ms. M. Arai and Ms. S. Tanimoto for secretarial work. We also thank Mr. K. Nagayoshi for assistance during FACS analysis. This work was supported by grants from the Life Science Research Project and the Fronteer Research Program of RIKEN and by a special fund from Nihon Kureha Chemical Inc.

\section{REFERENCES}

1. Bagchi, S., RaYchandhuri, P., and Nevins, J.R. (1990). Adenovirus E1A proteins can dissociate heteromeric complexes involving the E2F transcription factor: a novel mechanism for E1A transactivation. Cell, 62: 659-669.

2. Bandara, L.R., Adamczewski, J.P., Hunt, T., and La Thangue, N.B. (1991). Cyclin A and the retinoblastoma gene product complex with a common transcription factor. Nature (London), 352: 249-251.

3. Botchan, M., Grodzicker, T., and Sharp, P.A. (1986). Cancer Cells: RNA tumor viruses: Control of gene expression and replication, vol. 4. Cold Spring Harbor Laboratory, Cold Spring Harbor, New York.

4. Buchkovich, K., Duffy, L.A., and Harlow, E. (1989). The retinoblastoma protein is phosphorylated during specific phases of the cell cycle. Cell, 58: 1097-1105.

5. Chellappan, S.P., Hiebert, S., Mudryj, M., Horowitz, J.M., and Nevins, J.R. (1991). The E2F transcription factor is a cellular target for the RB protein. Cell, 65: 1053-1061.

6. Chen, D.-L., Scully, P., Shew, J.-Y., WANG, J.Y.J., and LEE, W.-H. (1989). Phosphorylation of the retinoblastoma gene products is modulated during the cell cycle and cellular differentiation. Cell, 58: 1193-1198.

7. Chirgwin, J.M., Aeybyle, A., MacDonald, R.J., and RUTTER, W.J. (1979). Isolation of biologically active ribonucleic acid from sources rich in ribonuclease. Biochemistry, 18: 5294-5299.

8. De Caprio, J.A., Ludlow, J.W., Figge, J., Shew, J., Huang, C.-M., Lee, W.-H., Marsillo, E., Paucha, E., and 
Livingston, D.M. (1988). SV40 large tumor antigen forms a specific complex with the product of the retinoblastoma susceptibility gene. Cell, 54: 275-283.

9. De Caprio, J.A., Ludlow, J.W., Lynch, D., Furukawa, Y., Griffin, J., PiWnica-Worms, H., Huang, C.-M., and Livingston, D.M. (1989). The product of the retinoblastoma susceptibility gene has properties of a cell cycle regulatory element. Cell, 8: 1085-1095.

10. Delbeare, F., Gratzner, H., Pallavicini, M.G., and Gray, J.W. (1983). Flow cytometric measurement of total DNA content and incorporated bromodeoxyuridine. Proc. Natl. Acad, Sci. USA., 80: 5573-5575.

11. Dimio, D. and Nathans, D. (1980). Cold-sensitive regulatory mutants of Simian Virus 40. J. Mol. Biol., 140: 129-142.

12. Dyson, N., Hoewley, P.M., Munger, K., and Harlow, E. (1989). The human papilloma virus-16E7 oncoprotein is able to bind to the retinoblastoma gene product. Science, 243: 934937.

13. Dyson, N., Bernards, R., Friend, S.H., Gooding, L.R., Hassel, J.A., Major, E.O., Pipas, J.M., VAN Dyke, T., and HaRlow, E. (1990). Large T antigens of many polyoma viruses are able to form complexes with the retinoblastoma protein. J. Virol., 64: 1353-1356.

14. Egan, D., Bayley, S.T., and Branton, P.E. (1989). Binding of the $R b 1$ protein to E1A products is required for adenovirus transformation. Oncogene 4: 383-388.

15. Feinberg, A.P. and Vogelstein, B. (1983). A technique for radio-labeling DNA restriction fragments to high specific activity. Anal. Biochem., 132: 6-13.

16. Friend, S.H., Horowitz, J.M., Gerber, M.R., WANG, X.F., Bogenmarn, E, Li, F.P., and Weinberg, R.A. (1987). Deletions of a DNA sequence in retinoblastomas and mesenchymal tumors: organization of the sequence and its encoded protein. Proc. Natl. Acad. Sci. USA., 84: 9059-9063.

17. Fukuchi, K., Tanaka, K., Nakura, J., Kumahara, Y., UChIDA, T., and OKaDA, Y. (1985). Elevated spontaneous mutation rate in SV40-transformed Werner Syndrome fibroblast cell line. Somatic Cell and Molecular Genetics, 11: 363-308.

18. Girardi, A.J., Weinstein, D., and Moorheas, P.S. (1966). SV40 transformation of human diploid cells: a parallel study of viral and karyologic parameters. Ann. Med. Exp. Biol. Fenn., 44: 242-254.

19. Gorman, C.M., Moffat, L.F., and Howard, B.H. (1982). Recombinant genomes which express chloramphenicol acetyltransferase in mammalian cells. Mol. Cell. Biol., 9: 1044-1051.

20. Green, P.J., Pines, O., and Inouye, M. (1986). The role of antisense RNA in gene regulation. Ann. Rev. Biochem., 55: 569-597.

21. Grove, G.L. and Cristofalo, V.J. (1977). Characterization of he cell cycle of cultured human diploid cells: effects of aging and hydrocortisone. J. Cell Physiol., 90: 415-422.

22. Harlow, E., Crawford, L.V., Pim, D.C., and Williamson, N.M. (1981). Monoclonal antibodies specific for simian virus 40 tumor antigens. Cell, 39: 861-869.

23. HAYFLICK, L. and MOORHEAD, P.S. (1961). The serial cultivation of human diploid cell strains. Exp. Cell Res., 25: 585-621.

24. Iguchui-Ariga, S.M.M., Itani, T., KiJi, Y., and Ariga, H. (1987). Possible function of the c-myc product: promotion of cellular DNA replication. EMBO. J., 6: 2365-2371.

25. Kaelin, W.G.JR, Ewen, M.E., and Livingston, D.M. (1990). Definition of the minimal simian virus 40 large $T$ antigen-and adenovirus E1A-binding domain in the retinoblastoma gene product. Mol. Cell. Biol., 10: 3761-3769.
26. Katoh, S., OzaWa, K., Кondoh, S., Sofda, E., Israel, A., Shiroki, K., Fujinaga, K., Itakura, K., GaChelin, G., and YoKoYAMA, K. (1990). Identification of sequences responsible for positive and negative regulation by $\mathrm{E} 1 \mathrm{~A}$ in the promoter of $\mathrm{H}-2 \mathrm{~K}^{\mathrm{bml}}$ class I MHC gene. EMBO. J., 9: 127-135.

27. Kim, S.-J., Lee, H.-D., Robbins, P.D., Busam, K., Sporn, M.B., and ROBERTS, A.B. (1991). Regulation of transforming growth factor $\beta 1$ gene expression by the product of the retinoblastoma-susceptibility gene. Proc. Natl. Acad. Sci. USA., 88: 3052-3056.

28. Kitabayashi, I., Chiu, R., Gachelin, G., and Yokoyama, K. (1990). E1A-dependent up-regulation of c-Jun/AP-1 activity. Nucleic Acids Res., 19: 649-655.

29. LaEMmili, U.K. (1970). Cleavage of structural proteins during the assembly of the head of bacteriophage T4. Nature (London), 227: 680-685.

30. Lee, W.-H., Bookstein, R., Hong, F.D., Young, L.-J., Shew, J.-Y., and LEE, E.Y.-H.P. (1987). Human retinoblastoma susceptibility gene: cloning, identification, and sequence. Science, 235: 1394-1399.

31. Ludiow, J.W., De Caprio, J.A., Hung, C.-M., Lee, W.-H., Paucha, E., and Livingston, D.M. (1989). SV40 large T antigen binds preferentially to an underphosphorylated member of the retinoblastoma susceptibility gene product family. Cell, 56: $57-65$.

32. Ludiow, J.W., Shon, J., Pipas, J.M., Livingston, D.M., and DE CAPRIO, J.A. (1990). The retinoblastoma susceptibility gene product undergoes cell cycle-dependent dephosphorylation and binding to and release from SV40 large T antigen. Cell, 60: 387-396.

33. Mihara, K., CaO, X.-R., Yen, A., Chandler, S., Driscoll, B., Murphere, A.L., T'ANG, A., and FunG, Y.-K.T. (1989). Cell cycle-dependent regulation of phosphorylation of the human retinoblastoma gene product. Science, 2246: 1300-1303.

34. Mitsui, Y., Yamamoto, K., Yamamoto, M., and Matsuoka, K. (1985). Cell surface changes in senescent and Werner's syndrome fibroblasts: their role in cell proliferation. Ann. Med. Exp. Biol., 190: 567-585.

35. Mudryu, M., Devoto, S.H., Hiebert, S.W., Hunter, T., Pines, J., and Nevins, J.R. (1991). Cell cycle regulation of the E2F transcription factor involves an interaction with cyclin A. Cell, 65: 1243-1253.

36. Munger, K., Werness, B.A., Dyson, N., Phelps, W.C., Harlow, E., and Howley, P.N. (1989). Complex formation of human papilloma virus $\mathrm{E} 7$ proteins with the retinoblastoma tumor suppressor gene product. EMBO. J., 8: 4099-4105.

37. Pientenpol, J.A., Stein, R.W., Moran, E., Yacicuk, D., Schlegal, R., Lyons, R.M., Pittelknow, M.R., Minger, K., Howley, P.M., and Moses, H.L. (1990). TGF- $\beta 1$ inhibition of $c-m y c$ transcription and growth in keratinoytes is abrogated by viral transforming proteins with pRB-binding domains. Cell, 61: 777-785.

38. Robiins, P.D., Horowits, J.M., and Mulligam, R.C. (1990). Negative regulation of human c-fos expression by the retinoblastoma gene product. Nature (London), 346: 668-671.

39. Rustagi, A.K., Dyson, N., and Bernards, R. (1991). Aminoterminal domain of $c-m y c$ and $N-m y c$ protein mediate binding to the retinoblastoma gene product. Nature (London), 352: 541-544.

40. Stein, G.H., Beeson, M., and Gordon, L. (1990). Failure to phosphorylate the retinoblastoma gene product in senescent human fibroblast. Science, 249: 606-669.

41. Thомаs, P. (1983). Hybridization of denatured RNA transfer- 
red or dotted to nitrocellulose paper. Meth. Enzymol., 100B: 255-266.

42. UlLRICH, A. and Schlessinger, J. (1990). Signal transduction by receptors with tyrosine kinase activity. Cell, 61: 203-212.

43. Varley, J.M., Armour, J., Swallow, J.E., Jeffreys, A.J., Ponden, B.A.J., T'Ang, A., Fung, Y.-K.T., Bramm, W.J., and WALKER, R.A. (1989). The retinoblastoma gene is frequently altered leading to loss of expression in primary breast tumors. Oncogene, 4: 725-729.

44. Weintraub, H., Izant, J.G., and Harland, R.M. (1985). Antisense RNA as a molecular tool for genetic analysis. Trends $G e-$ net., 1: 22-25.

45. Whyte, P., Buchkovich, K., Horowitz, J.M., Friend, S.H., RaybucK, M., Weinberg, R.A., and Harlow, E. (1988). Association between an oncogene and an antioncogene: the adenovirus E1A proteins bind to the retinoblastoma gene product. $\mathrm{Na}$ ture (London), 334: 124-129.

46. Wigler, M., Pellicer, A., Silverstein, S., Axel, R., Urlaub, G., Wold, B., Peliticer, A., Lacy, E., and Chasin, L. (1979). DNA-mediated transfer of the adenine phosphoribosyl transferase locus into mammalian cells. Proc. Natl. Acad. Sci. USA., 76: 1373-1376.
47. Yee, A.S., Raychandhuri, P., Jakoi, L., and Nevins, J.R. (1989). The adenovirus-inducible factor E2F stimulates transcription after specific DNA-binding. Mol. Cell. Biol., 9: 578585.

48. Yoкочама, K. and Iмамото, F. (1987). Transcriptional control of the endogenous myc protooncogene by antisense RNA. Proc. Natl. Acad. Sci. USA., 84: 7363-7367.

49. Yокочама, K. (1991). Transcriptional regulation of $c$-myc protooncogene by antisense RNA. In Prospects for Antisense Nucleic Acid Therapy of Cancer and AIDS (E. Wickstom, ed.). Wiley-Liss Inc., New York, pp. 35-51.

50. YoKоYAMA, K. (1992). Antisense RNA induces a nuclear transcription factor to repress the expression of endogenous $m y_{C}$ gene. In Antisense RNA and DNA (Harford, J. and Murray, J.A.H. eds.). Wiley-Liss Inc., New York, pp. 335-352.

(Received for publication, August 11, 1992 and in revised form, October 22, 1992) 